\title{
Ecological parameters of the (S)-9- methylgermacrene-B population of the Lutzomyia longipalpis complex in a visceral leishmaniasis area in São Paulo state, Brazil
}

\author{
Fredy Galvis-Ovallos ${ }^{* *}$, Claudio Casanova², Anaiá da Paixão Sevá ${ }^{3}$ and Eunice Aparecida Bianchi Galati ${ }^{4}$
}

\begin{abstract}
Background: Visceral leishmaniasis (VL) is an important public health challenge in Brazil because of the high number of human and canine cases reported annually. Leishmania infantum is the etiological agent of VL and Lutzomyia longipalpis is its main vector. However, evidence suggests that this taxon constitutes a species complex. In Sao Paulo state, there are two populations of Lu. longipalpis, each secreting distinct pheromones, (S)-9-methylgermacrene-B and Cembrene 1; both have been associated with different patterns of VL transmission. The aim of the present study was to investigate the temporal distribution and natural infection of the (S)-9-methylgermacrene-B population of the Lu. longipalpis complex in a highly VL endemic area of Sao Paulo state to obtain information that may contribute to the surveillance of this zoonosis and to the planning of preventive and control measures.
\end{abstract}

Methods: The study was carried out in Panorama municipality, Sao Paulo State. Captures were made during 24 months in seven domiciles. The relation between sand fly abundance and climatic variables, temperature and humidity, was analyzed and natural infection by Leishmania spp. in sand fly females was investigated by nested PCR.

Results: A total of 4120 sand flies, with predominance of Lu. longipalpis (97.2\%) were captured. The highest averages of sand flies/night/trap occurred in the rainy season (November-March) and a positive, significant correlation between sand fly abundance and the temperature and humidity 20 days before the capture days was found. Leishmania infantum DNA was detected in three out of 250 pools of females analyzed, giving an estimated minimum infection rate of 1.2\%.

Conclusion: The identification of the climatic association between the high abundance of the vector in this highly endemic VL focus constitutes a fundamental point for evaluating future vector and dog control measures and this information increases the data of VL foci in Sao Paulo state that could contribute to the public health authorities in planning prevention and control measures. The identification of natural infection by Le. infantum in Lu. longipalpis specimens reinforces the importance of entomological surveillance activities in this municipality.

\section{Background}

The phlebotomine sand flies (Diptera: Psychodidade) are of epidemiological importance due to the involvement of several species in the transmission of pathogenic agents of diseases such bartonelloses, arboviruses and mainly the leishmaniasis [1, 2]. From 1999 to 2013, there were recorded in Brazil 53,067 new cases of visceral leishmaniasis (VL), with an annual mean of 3500 new cases. From

\footnotetext{
* Correspondence: galvisfregao@gmail.com

'Programa de Pós-Graduação em Saúde Pública, Faculdade de Saúde

Pública, Universidade São Paulo - USP, São Paulo, SP, Brazil

Full list of author information is available at the end of the article
}

1999 to 2013 São Paulo state, recorded 2328 new cases of the disease distributed in 80 municipalities, with 202 deaths [3]. Of the 520 existing American sand flies described [4], Lutzomyia longipalpis is the Neotropical species most widely studied because of its epidemiological importance as the main vector of Leishmania infantum, agent of VL [5-7]. This species occur from Mexico to Argentina, with the exception of Ecuador, Peru and Chile, and is widely distributed in Brazil where has shown in recent years that it is well adapted to urban areas [8]. Undoubtedly, this fact has further contributed to its rapid expansion [6-9] and constitutes a challenge 
to VL control programs [7, 10]. Until 2015, Lu. longipalpis has been reported in 177 municipalities of São Paulo state [11]. However ecological, biochemical and genetic evidences suggest that this species is in fact a cryptic species complex $[5,12,13]$ of which at least four different populations have been identified in Brazil [13]. Some authors have suggested that the taxa of these sibling species could present differences in their vectorial capacities [14-19]. In Sao Paulo state only two populations of this complex has been identified, (S)-9-methylgermacrene-B and Cembrene-1, each one have been associated with areas presenting distinct VL epidemiological patterns $[18,19]$. While the Cembrene-1 population is considered native and distributed in the Eastern region of São Paulo state, where no human cases has been recorded, the (S)9-methylgermacrene-B was identified for the first time in São Paulo in $1997[18,19]$ and is considered a more recently introduced population that occupies Western areas, with occurrence of human cases [18]. In the light of the remarkable epidemiological differences between these regions of São Paulo state, Casanova et al. [18, 19] have suggested that the (S)-9-methylgermacrene-B and Cembrene-1 - chemotype populations could have different vectorial capacities in this state. These differences call attention because in the Northeastern region of Brazil the Cembrene- 1 population is abundant and related to human VL cases while that of (S)-9-methylgermacrene- $B$ is rare [20]. These differences could be related to ecological parameters and for this reason studies evaluating aspects of these populations such as the spatial-temporal distribution (abundance, seasonal distribution), natural infection and blood feeding habits, among others, can contribute to the elucidation of the differences between the populations [19] and their role in the transmission of the VL agent in endemic areas.

Climatological variables such as temperature and precipitation can affect biological aspects of hematophagous insects, among these the duration of the immature development and the gonotrophic cycle. Therefore, they influence the spatial-temporal distribution of vectors and produce seasonal patterns [21] and indirectly influences parameters related to the vectorial capacity such as the vector density by host and the biting rate [22]. For this reason, the vector density is a useful indicator in the epidemiological surveillance of vector-borne diseases [23]. Additionally, the vector frequencies are associated with the vegetal cover and density/diversity of the hosts $[24,25]$, which determine the type and quantity of blood meal sources and the availability of natural shelters, influencing the vector's contact with a competent host and the prevalence of infection in the vectors. Further, the natural infection estimates in vectors could be used as indicator of transmission intensity to the host, hence determining risk areas.
In Panorama municipality, Lu. longipalpis was detected by the first time in 2005 [26] and during the period from 2007 to 2009, 28 human VL cases were notified. According to the to the criteria of the Brazilian Health Ministry to stratify transmission areas for the implementation of prevention and control measures this represent an intense transmission (mean cases number in a period of three years $\geq 4.4$ [27]. Based on the number of cases reported [28], between 2009 and 2011 the transmission was moderate $(\geq 2.4)$ and between 2013 and 2015 the transmission was sporadic $(\leq 2.4)$. Considering the endemic character of the VL in this municipality and the epidemiological importance of the vector, this study was designed to investigate the temporal distribution and natural infection of a population of the $L u$. longipalpis complex in this local to obtain information that may contribute to zoonotic VL surveillance and to the planning of preventive and control measures.

\section{Methods \\ Study area}

Panorama municipality is located in the western region of São Paulo state at $21^{\circ} 21^{\prime} 23^{\prime \prime} \mathrm{S}$ and $51^{\circ} 51^{\prime} 35^{\prime \prime} \mathrm{W}$. Its average annual temperature varies between a minimum of $12{ }^{\circ} \mathrm{C}$ and a maximum of $35{ }^{\circ} \mathrm{C}$; the rainy season occur from October to March. According to Köppen - Geiger's classification, the climate is tropical with a dry winter [29]. This region belongs to the Atlantic forest biome, with a population estimated at 14,583 inhabitants, and $95 \%$ of them living in urban area [30]. The main economic activities are general services and the ceramics industry. This municipality was selected due to its high annual average numbers of VL human cases and the high canine seroprevalence (41\%) [31]. Seven domiciles of the urban area were selected for the entomological survey due to the presence of ecotopes appropriate to sand flies, such as chickencoops or shelters of other domestic animals, and vegetation (Fig. 1).

\section{Sand fly captures}

The captures were performed with automatic light traps installed in the domiciles during two years between July 2012 and June 2014. In each domicile one trap was installed in the porch of the house and another in the peridomicile (animal shelters or vegetation located between 10 and $20 \mathrm{~m}$ from the house). The traps were lighted on four consecutive days each month during the first year and on three consecutive days in the second year, in the period between 17:00 and 07:00 h. Among the insects captured a sample of live sand fly females was dissected to investigate natural infection by flagellates in their guts. The other insects were killed by freezing for $10 \mathrm{~min}$ and then the samples were screened. The sand flies were counted and 


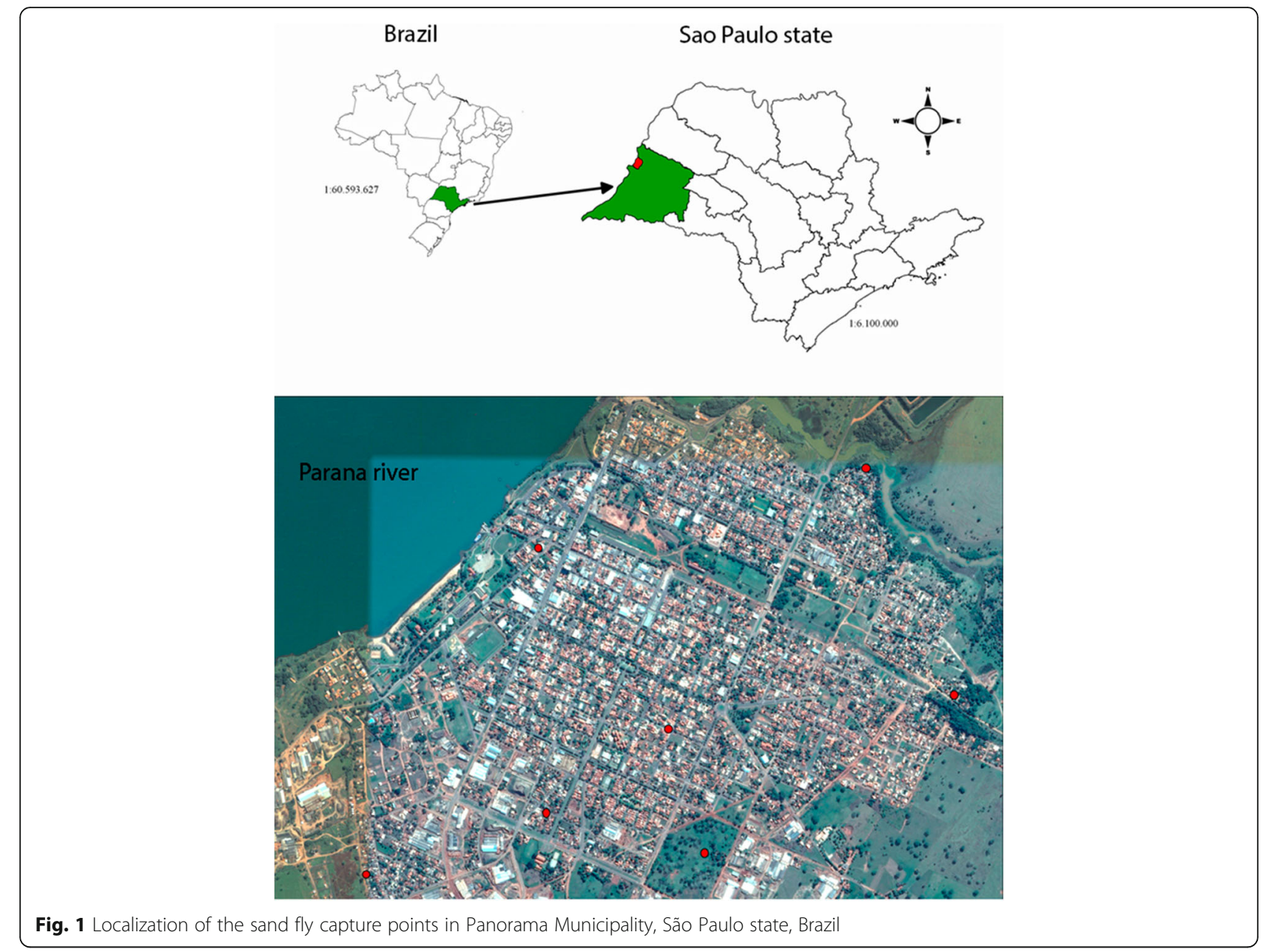

registered according to place of capture and collection date. The specimens were stored in ethanol $70 \%$. The head and the terminal part of the abdomen of a sample of the females were severed from the rest of the body, clarified and identified in accordance to the literature $[1,32]$ and the rest of their bodies were stored for later analysis of natural infection with Leishmania sp. by molecular methods. Additionally, the blood feeding state (engorged or non-engorged) and the presence of eggs in the abdomen were observed because this information is an indirect indication of the risk of infection [33].

\section{Pheromone identification}

To identify the Lu. longipalpis chemotypes present in the study area specimens captured in 2013 in different places of the Panorama municipality were reared under laboratory conditions to obtain F1 specimens. The natural pheromone test was undertaken on individual $(n=6)$ 5-day-old F1 males. The test was applied according to the method described in Casanova et al. [18].

\section{Natural infection analysis}

A sample of 150 live females were dissected for the parasitological analysis performed as described by Diniz et al. [34]. Another sample of 652 females was grouped into pools for analysis by Nested-PCR. Each pool ranging from between 1 and 10 females consisted of specimens captured in the same place and date.

\section{DNA extraction}

The DNA extraction was performed using a modified method of Brufford et al. [35]. Initially the alcohol used to store the samples was discarded and $20 \mu \mathrm{l}$ of a lyses solution (Digsol buffer) was added to each pool together with $20 \mu \mathrm{l}$ of Proteinase $\mathrm{K}(10 \mathrm{mg} / \mathrm{ml})$ and the samples were incubated for $3 \mathrm{~h}$ at $55-60{ }^{\circ} \mathrm{C}$. Thereafter $400 \mu \mathrm{l}$ of ammonium acetate $(4 \mathrm{M})$ was added, the samples homogenized by vortex for $15 \mathrm{~min}$ and centrifuged for $15 \mathrm{~min}$ at $13,000 \mathrm{rpm}$ at $10{ }^{\circ} \mathrm{C}$. The supernatant was transferred to another tube and $1 \mathrm{ml}$ of ethanol 100\% added and centrifuged at $15,000 \times \mathrm{rpm}$ for $15 \mathrm{~min}$ for DNA precipitation. Finally, $900 \mu \mathrm{l}$ of $70 \%$ cold ethanol was added, stirred 
and the supernatant discarded. After dry, the tube $50 \mu \mathrm{l}$ of Tris-EDTA buffer was added to re-suspend the pellet.

\section{Nested PCR for detection and identification of Leishmania spp. in the sand flies}

To identify the Leishmania species in the sand flies, a nested PCR of the SSU rRNA gene ( $561 \mathrm{bp})$, which corresponds to partial sequence of the variable V7V8 region of the SSU rRNA gene, was carried out according to Noyes et al. [36]. For positive control, we used DNA of females of $\mathrm{Lu}$. longipalpis experimentally infected with Le. infantum. The PCR-amplified products were sequenced and the generated sequences were submitted to BLAST [37] search in the GenBank database. The sequences obtained were deposited into the GenBank ESTs database with accession numbers MF000384 and MF000385.

\section{Statistical analyses}

Considering the differences in the sampling in the first year (4 nights per month) and the second year (three nights per month), the number of Lu. longipalpis specimens collected was standardized as the number of specimens/trap/night. The climatic data were obtained from the meteorological station of Pauliceia municipality located $10 \mathrm{~km}$ from Panorama. These data were obtained from the website of the São Paulo state Integrated Center of Agrometeorological Information (CIIAGRO) [38]. A non-parametric analysis of correlation (Spearman's rank correlation) was undertaken to evaluate the association between the values of specimens of $\mathrm{Lu}$. longipalpis/trap/night and the total monthly rainfall 20, 10 days before and on the capture-day and similarly with the average of the temperature values 20 and 10 days before capture and on the capture-day. The analyses were performed by the SPSS V.17 program. In addition, using the Poisson regression, we evaluated the associations between environmental variables and the monthly sand fly density. Thus, the rate ratio (RR) and 95\% confidence interval $(95 \% \mathrm{CI})$ were estimated in both simple and multiple models. The natural infection rate was estimated as the number of positive pools in the total of pools tested, as suggested by Paiva et al. [39].

\section{Results}

\section{Chemotype identification}

In the analysis of the sexual pheromones, all six samples of Lu. longipalpis males tested presented the (S) -9-methyl-germacrene B.

\section{Temporal distribution}

A total of 4430 sand flies (1147 females and 3283 males) of six species were captured during the study. Lutzomyia longipalpis was the most common species accounting for $97.2 \%$ of the specimens captured, with a male/female ratio of 3:1. The number of males and females by species is presented in Table 1. Differences in the male/female ratio were observed in all the months sampled, with higher frequencies of males.

The highest average numbers of sand flies/night/trap were obtained during the rainy season (NovemberMarch) with a peak in both male and female abundance in March of both years investigated (Table 2, Fig. 2). With the exception of July and August 2013, Lu. longipalpis was collected in all the months sampled with the highest abundance occurring in the period from January to March in both years sampled (Fig. 2).

A positive and significant correlation was detected between the numbers of males (specimens/trap/night) and the minimum temperature values 10 days before the collection $(r=0.47, P=0.02)$. A positive association with the minimum temperature and the total rainfall 20 days before the collection was observed for both sexes (Table 3).

In the analysis of the association of these variables, we observed a biological gradient between environmental variables and total sand fly abundance. Therefore, we have represented these associations by obtaining rate ratios of sand fly counts per unit of both temperature and rainfall. Thus, we estimated, in a multiple model, that sand fly frequencies increase about $22 \%$ for each $50 \mathrm{~mm}$ of cumulative rainfall (Rate ratio, RR: 1.22 ; $95 \%$ CI: $1.18-1.25$ ); and about $12 \%$ for each degree of minimal temperature (RR: 1.12; $95 \%$ CI: 1.1-1.14).

Among the 733 females observed to evaluate the blood feeding state and the presence of eggs, 468 were captured in the peridomicile and 265 in house porches. Among those captured in the peridomicile, 75 females (16.0\%) were engorged, 7 (1.5\%) were engorged and carrying eggs and 35 (7.5\%) had only eggs. Between the females captured in the porches, 21 were engorged $(7.9 \%)$, one $(0.4 \%)$ was engorged and carrying eggs and $13(4.5 \%)$ only had eggs.

Table 1 Number of specimens by species and sex captured in Panorama municipality between July 2012 and June 2014

\begin{tabular}{lllllll}
\hline Species & Females & $\%$ & Males & $\%$ & Total & $\%$ \\
\hline Lutzomyia longipalpis & 1087 & 25.2 & 3220 & 74.8 & 4307 & 97.22 \\
Nyssomyia neivai & 35 & 56.5 & 27 & 43.5 & 62 & 1.40 \\
Evandromyia lenti & 19 & 38.8 & 30 & 61.2 & 49 & 1.11 \\
Evandromyia carmelinoi & 2 & 28.6 & 5 & 71.4 & 7 & 0.16 \\
Evandromyia cortelezzi & 3 & 100.0 & 0 & 0 & 3 & 0.07 \\
Brumptomyia brumpti & 1 & 50.0 & 1 & 50.0 & 2 & 0.05 \\
Total & 1147 & & 3283 & & 4430 & 100 \\
\hline
\end{tabular}


Table 2 Monthly values of males and females of Lutzomyia longipalpis, minimum and maximum values of temperature and total values of rainfall in the study area

\begin{tabular}{|c|c|c|c|c|c|c|c|}
\hline \multirow[t]{2}{*}{ Month/Year } & \multirow[t]{2}{*}{ Temp $\max 20^{\mathrm{a}}$} & \multirow[t]{2}{*}{$T e m p_{\min } 20^{b}$} & \multirow[t]{2}{*}{ Total rainfall $20^{c}$} & \multicolumn{2}{|c|}{ Total no. of specimens } & \multicolumn{2}{|c|}{ No. of specimens/trap/night } \\
\hline & & & & Females & Males & Females & Males \\
\hline $\mathrm{Jul} / 12$ & 27.1 & 14.5 & 106.7 & 53 & 115 & 0.83 & 1.8 \\
\hline Aug/12 & 30.5 & 15.9 & 0.0 & 55 & 153 & 0.86 & 2.39 \\
\hline Sep/12 & 32.2 & 15.7 & 0.0 & 35 & 131 & 0.73 & 2.73 \\
\hline Oct/12 & 31.3 & 17.7 & 48.0 & 71 & 253 & 1.11 & 3.95 \\
\hline Nov/12 & 33.9 & 20.9 & 44.7 & 59 & 191 & 0.92 & 2.98 \\
\hline $\mathrm{Dec} / 12$ & 34.7 & 21.8 & 54.4 & 28 & 134 & 0.44 & 2.09 \\
\hline $\mathrm{Jan} / 13$ & 32.7 & 21.3 & 110.4 & 49 & 227 & 1.02 & 4.73 \\
\hline $\mathrm{Feb} / 13$ & 32.2 & 20.8 & 219.5 & 120 & 192 & 1.88 & 3.0 \\
\hline Mar/13 & 32.5 & 20.8 & 134.7 & 124 & 364 & 1.94 & 5.69 \\
\hline Apr/13 & 29.1 & 17.8 & 65.5 & 78 & 229 & 1.22 & 3.58 \\
\hline May/13 & 30.0 & 14.6 & 1.3 & 69 & 180 & 1.08 & 2.81 \\
\hline Jun/13 & 28.7 & 15.9 & 52.7 & 15 & 53 & 0.23 & 0.83 \\
\hline $\mathrm{Jul} / 13$ & 28.6 & 14.7 & 42.2 & 0 & 0 & 0 & 0 \\
\hline Aug/13 & 30.2 & 11.9 & 0 & 0 & 0 & 0 & 0 \\
\hline Sep/13 & 33.3 & 17.1 & 42.1 & 8 & 20 & 0.19 & 0.48 \\
\hline Oct/13 & 32.8 & 19.2 & 34.8 & 15 & 29 & 0.36 & 0.69 \\
\hline Nov/13 & 33.6 & 19.9 & 36.2 & 24 & 54 & 0.57 & 1.29 \\
\hline $\mathrm{Dec} / 13$ & 35.3 & 21.1 & 52.2 & 30 & 112 & 0.71 & 2.67 \\
\hline Jan/14 & 33.5 & 20.4 & 83.7 & 57 & 250 & 1.36 & 5.95 \\
\hline $\mathrm{Fev} / 14$ & 35.5 & 20.7 & 83.9 & 37 & 49 & 0.88 & 1.17 \\
\hline Mar/14 & 33.3 & 20.2 & 77.8 & 104 & 348 & 2.49 & 8.29 \\
\hline Apr/14 & 30.3 & 18.7 & 59.1 & 31 & 127 & 0.74 & 3.02 \\
\hline May/14 & 31.6 & 16.2 & 25.1 & 0 & 4 & 0 & 0.14 \\
\hline Jun/14 & 30.2 & 14.8 & 0 & 10 & 20 & 0.74 & 0.48 \\
\hline
\end{tabular}

${ }^{a}$ Average maximum temperature 20 days before the capture

${ }^{\mathrm{b}}$ Average minimum temperature 20 days before the capture

'Total value for precipitation 20 days before the capture

\section{Natural infection}

In the samples of females dissected $(n=150)$ no flagellates were detected in the guts. By using the nested PCR method, a total of 308 pools were analyzed, of which 251 were of Lu. longipalpis, 25 of Ny. neivai, 18 of Ev. lenti, 12 of Ev. cortelezzii and two of Brumptomyia sp. Only three pools of $\mathrm{Lu}$. longipalpis were positive for Leishmania sp.; of these, two were females captured in the porch of the same domicile, one with 10 females captured in March 2013 and the second with 6 females captured in June 2014; in both pools there was a female with some remaining eggs in its abdomen. The third positive sample was represented by one female without eggs in its abdomen captured in January 2014 in the peridomicile of a different domicile.

In the alignment of the sequences obtained from the positive samples, a correspondence was observed with those of Le. infantum deposited in the GenBank and which clearly differed from those of other species of the subgenera Leishmania and Viannia. Thus, a minimum infection rate of $1.2 \%$ of Lu. longipalpis with L. infantum was estimated.

\section{Discussion}

The first step for planning an effective vector-born disease control program is the identification of the species, which could be acting as vectors and their spatial-temporal distribution in order to identify the periods of highest risk of transmission [23]. Our results of chemotypes analyses of the male samples of Panorama municipality shown to contain the pheromone (S)-9-methylgermacrene-B exclusively. This results is concordant with previous reports in others ten municipalities of the West region of Sao Paulo state [18]. The presence of Lu. longipalpis at all the points sampled was observed during the $22 / 24$ months 


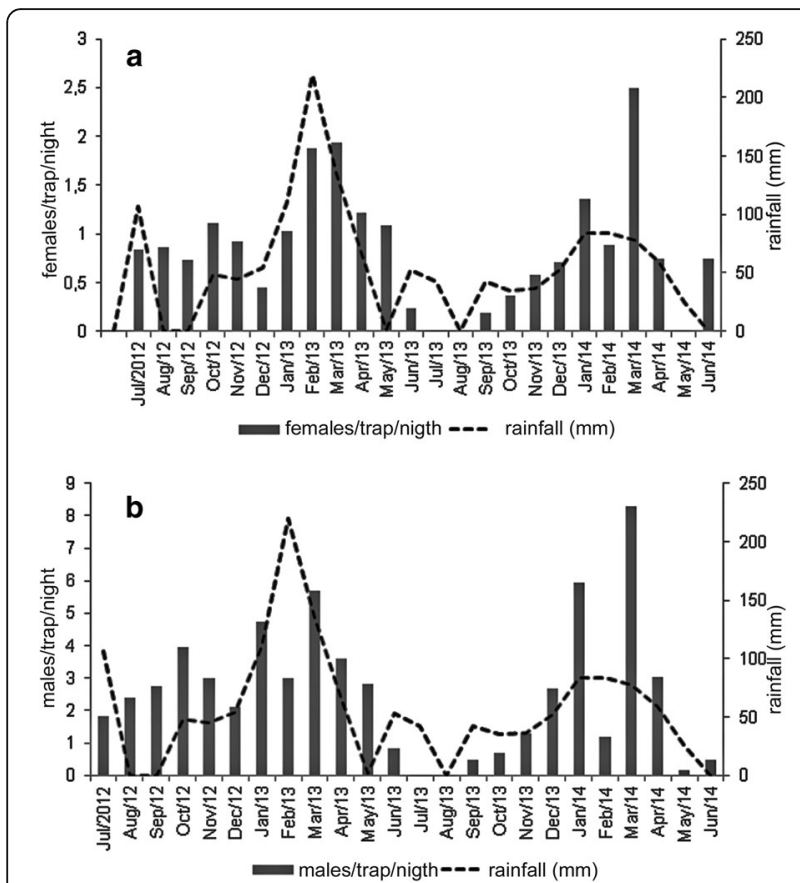

Fig. 2 Monthly distribution of females (a) and males (b) of Lutzomyia longipalpis and the total rainfall 20 days before the capture in Panorama (SP) in the period from July 2012 to June 2014

of captures with an average male/female ratio of 3:1. The high abundance of this sand fly observed in the study could be explained by the characteristics of the landscape of the area studied including peridomiciles with some fruit trees and domestic animal shelters, which offer conditions favorable to the development of immature forms of Lu. longipalpis and where the adults can find sources of blood and sugar [40, 41]. The predominance of males might be related to the presence of hosts and as a response to aggregation pheromones liberated by males to attract conspecific specimens on the animals as observed in other $L u$. longipalpis population in VL focus in Brazil [42, 43] and also to the more intense activity of the males in the animal shelters [42] where the light traps were installed, increasing their capture chances.

Our results suggest a predominance of nulliparous females (75.0-85.0\%) in the ecotopes evaluated among the females captured and analyzed to evaluate blood feeding and the state of egg development. However, there was a remarkably high proportion of females carrying eggs in the peridomicile $(7.5 \%)$ and in the porches $(4.5 \%)$. This information suggests the circulation of females with complete digestion of the blood meal near the domicile and with potential to take a blood meal, indicating a risk to the human and canine populations [33].

We also observed that in the study area, the high density of $\mathrm{Lu}$. longipalpis population occurred in the rainy season with the highest abundance in the period from October to March. These observations are consistent with the results obtained in other VL foci in Brazil for other populations of the Lu. longipalpis complex [44-46]. This distribution could be corroborated by the observation of a positive and significant association between the abundance of $\mathrm{Lu}$. longipalpis and the values of total rainfall 20 days before the capture and between values of minimum temperature. In the analysis of the association between the climatic variables and sand fly abundance, it was estimated that the abudance of $L u$. longipalpis increased $22 \%$ for each $50 \mathrm{~mm}$ of increased rainfall and $11 \%$ for each degree increase in minimum temperature. Our results reinforce those of previous studies reporting an effect of rainfall on the distribution of this species. This fact could be related to the maintenance of soil humidity favorable to the development of immature forms [47], while the temperature could influence parameters such as the duration of the immature cycle, blood-feeding rate and the duration of the

Table 3 Values of the Spearman's correlation between the climatological variables and the frequency of males and females of Lutzomyia longipalpis

\begin{tabular}{llllll}
\hline Variable & \multicolumn{2}{l}{ Males/trap/night } & & Females/trap/night \\
\cline { 2 - 3 } \cline { 5 - 6 } & Spearman's coefficient & Significance level (95\%) & & Spearman's coefficient & Significance level (95\%) \\
\hline PT10D $^{\text {a }}$ & 0.21 & 0.32 & 0.30 & 0.14 \\
TMX10D $^{b}$ & 0.26 & 0.20 & 0.03 & 0.90 \\
TMN10D $^{c}$ & $0.47^{*}$ & 0.02 & 0.39 & 0.05 \\
PT20D $^{d}$ & $0.52^{*}$ & 0.01 & $0.63^{*}$ & $<0.001$ \\
TMX20D $^{\text {e }}$ & 0.27 & 0.19 & 0.18 & 0.38 \\
TMN20D $^{\text {f }}$ & $0.50^{*}$ & 0.01 & $0.44^{*}$ & 0.03 \\
\hline
\end{tabular}

*P $<0.05$; values statistically significant

${ }^{\text {a } T o t a l ~ r a i n f a l l ~} 10$ days before the capture

${ }^{\mathrm{b}}$ Average maximum temperature 10 days before the capture

${ }^{\mathrm{C}}$ Average minimum temperature 10 days before the capture

${ }^{\mathrm{d}}$ Total rainfall 20 days before the capture

${ }^{\mathrm{e}}$ Average maximum temperature 10 days before the capture

${ }^{f}$ Average minimum temperature 10 days before the capture 
gonotrophic cycle [25, 48, 49]. In Dracena (SP) municipality located at $30 \mathrm{~km}$ from Panorama where the same chemotype of Lu. longipalpis was identified [18], the same pattern of distribution in a long-term study using automatic light traps has been observed [50]. Thus, our results suggest that the risk of transmission of $L$. infantum in Panorama municipality increases in the rainy season. Therefore, the present results may serve as a guide for the control strategies recommended by the Health authorities focused on the vector, such as the application of residual insecticides [27] and environmental management measures, and also to the evaluation and implementation of large-scale programs such as the use of collars impregnated with insecticides and vaccines to protect dog populations.

In the present study we also analyzed the natural infections with Leishmania sp. of specimens of five species (91.9\% of Lu. longipalpis) by parasitological and molecular tests. In the parasitological analyses by dissection, no flagellates were observed in the gut of the females examined. This result could be related to the higher activity of nulliparous females seeking blood-feeding sources (> 75\%), captured in the CDC traps. Perhaps the use of other methods to capture engorged females in the shelters could result in rates closer to those found by other authors, which vary between 0.2 and $7.14 \%$ [51, 52].

To evaluate a natural infection of females samples by Leishmania species, the molecular analysis by nested PCR was used. More recently molecular methods have been supporting entomological surveillance activities due to their higher sensitivity, the specificity of parasite identification and especially the possibility of analyzing a greater number of specimens [53]. Among the species captured in the focus, only females of $\mathrm{Lu}$. longipalpis were positive to infection with Le. infantum rendering a minimum infection rate of $1.2 \%$. Using molecular methods, infection rates ranging between 0.25 and 3.9\% have been reported in other foci of VL in Brazil [39, 53-55]. These differences could be related to variations in the sensitivity and specificity of the method for identification of the parasite. However, it is emphasized that natural infection in vectors is likely to vary between localities because it depends on factors such as the capture method, host abundance and parasite prevalence in the focus, among others.

The low infection rate in the sand flies observed in this study contrasts with the high canine prevalence (around 40\%) in the study area in recent years [26, 31], that increase the risk of infection to humans. However, the identification of females carrying Le. infantum DNA captured in two $(28.5 \%)$ of the seven domiciles sampled, demonstrate a co-circulation of infected host and competent vectors with potential risk to the humans and reinforces the necessity of control vector measures.
The domiciles where potentially infective females were captured were characterized by the presence of abundant blood-feeding sources (hens, dogs, pigs), a factor that favors vector density and the maintenance of the transmission cycle and shows a distribution pattern indicative of a hot-spot [6]. Among the pools with specimens infected with Le. infantum, two were formed of females captured in the porch of the domicile and one in the peridomicile, suggesting the contact of competent vectors and some infected host near human domiciles, with the presence of all the components of the nidus of infection [25]. The identification of periods of increased Lu. longipalpis abundance and of the circulation of infected females reinforces the necessity of investigation of other vector bionomic parameters related to vectorial capacity, such as survival, vector competence and the density per host among others [22], that contribute to the development of prevention and control measures for VL by health authorities.

\section{Conclusions}

Our results emphasize the vectorial potential of the (S)9-methyl germacrene B population, whose chemotype has been spreading throughout the western municipalities of São Paulo state, with serious implications for the emergence of VL in this area [18], and for the first time describe ecological parameters for this chemotype of the Lu. longipalpis complex. This information constitutes the basis for future evaluation of the vector and dog control measures in this highly endemic VL focus. In view of the fact that Panorama municipality belongs to the most intense VL transmission region in São Paulo, our study contributes ecological data to increase knowledge on sand fly ecology in this region. Further studies evaluating parameters of the vectorial capacity such as survival, host-biting rate, blood feeding habit of this $L u$. longipalpis chemotype are necessary to the comprehension of the VL dynamics, as well as to evaluate the existence of differences in the vectorial capacity of this chemotype as suggested by some studies $[18,19]$.

\section{Abbreviations \\ DNA: Deoxyribonucleic acid; PCR: Polymerase chain reaction; VL: Visceral leishmaniasis}

\footnotetext{
Acknowledgements

We would like to thank the residents where the captures of sand flies were undertaken and the team of the epidemiological surveillance of Panorama municipality by its assistance in the captures. Thanks are due to Drs Marta Geraldes Texeira, Luciana Lima, Paola Ortiz and Oneida Espinosa from the Departamento de Parasitologia, Instituto de Ciências Biomédicas of the Sao Paulo University for their assistance in the natural infection research; to Tatiana Marques and Cecilia Oliveira for their laboratory assistance and to FAPESP for the financial support (fellowship to FGO). We also are grateful to Fredi A. Diaz-Quijano for his help with the statistical analysis.
} 


\section{Funding}

This study was supported by the São Paulo Research Foundation FAPESP process 12/03571-4 and 11/23541-1.

\section{Availability of data and materials}

The sequences obtained of Leishmania infantum were submitted in the Genbank EST database with accession numbers MF000384 and MF000385.

\section{Authors' contributions}

FGO and EABG designed the study. FGO collected the samples. FGO, EABG CC and APS performed the analysis and interpretation of data and in writing the manuscript. All authors read and approved the final manuscript.

\section{Competing interests}

The authors declare that they have no competing interests.

\section{Consent for publication}

Not applicable.

\section{Ethics approval and consent to participate}

Not applicable.

\section{Publisher's Note}

Springer Nature remains neutral with regard to jurisdictional claims in published maps and institutional affiliations.

\section{Author details}

${ }^{1}$ Programa de Pós-Graduação em Saúde Pública, Faculdade de Saúde Pública, Universidade São Paulo - USP, São Paulo, SP, Brazil.

${ }^{2}$ Superintendência de Controle de Endemias, Secretaria de Estado da Saúde, Mogi Guaçu, São Paulo, Brazil. ${ }^{3}$ Programa de Pós-Graduacão em Epidemiologia Experimental Aplicada às Zoonoses, Faculdade Medicina Veterinária, Universidade de São Paulo-USP, São Paulo, SP, Brazil. ${ }^{4}$ Departamento de Epidemiologia, Faculdade de Saúde Pública, Universidade São Paulo - USP, São Paulo, SP, Brazil.

Received: 31 December 2016 Accepted: 22 May 2017 Published online: 30 May 2017

References

1. Forattini OP. Entomologia médica. Psychodidae. Phlebotominae. Leishmaniose. Bartonelose. São Paulo: Editora Edgard Blücher Ltda; 1973.

2. Depaquit J, Grandadam M, Fouque F, Andry PE, Peyrefitte C. Arthropodborne viruses transmitted by phlebotomine sand flies in Europe: a review. Euro Surveill. 2010;15(10):19507

3. Rangel O, Oliveira SS, França AC, Ciaravolo RC, Henriques LF. Viscera leishmaniasis in the state of São Paulo: general trend of lethality from 1999 to 2013 and the risk of death by epidemiological stratification of the municipalities and regional epidemiological surveillance between 20112013. BEPA. 2015;12(143):1-8.

4. Galati EAB. Phlebotominae (Diptera: Psychodidae): Classificação, morfologia, terminologia e identificação de adultos. Apostila da Disciplina HEP 5752 Bioecologia e Identificação de Phlebotominae. São Paulo: Faculdade de Saúde Pública. Universidade de São Paulo; 2016. p. 1-120.

5. Lainson R, Rangel EF. Lutzomyia longipalpis and the eco-epidemiology of American visceral leishmaniasis. with particular reference to Brazil: a review. Mem Inst Oswaldo Cruz. 2005:100(8):811-27.

6. Rangel EF, Vilela ML. Lutzomyia longipalpis (Diptera: Psychodidae: Phlebotominae) and urbanization of visceral leishmaniasis in Brazil. Cad Saude Publica. 2008;24(12):2948-52

7. Salomón OD, Feliciangeli MD, Quintana MG, Afonso MM, Rangel EF. Lutzomyia longipalpis urbanisation and control. Mem Inst Oswaldo Cruz. 2015;110(7):831-46.

8. Brazil RP. The dispersion of Lutzomyia longipalpis in urban areas. Rev Soc Bras Med Trop. 2013;46(3):263-64

9. Mestre GL, Fontes CJ. The spread of the visceral leishmaniasis epidemic in the State of Mato Grosso 1998-2005. Rev Soc Bras Med Trop. 2007; 40(1):42-8.

10. Maia-Elkhoury AN, Alves WA, Sousa-Gomes ML, Sena JM, Luna EA. Visceral leishmaniasis in Brazil: trends and challenges. Cad Saude Publica. 2008;24: 2941-47.
11. Ciaravolo RMC, Oliveira SS, Hiramoto RM, Henriques LM, Taniguchi HH, Junior AV, et al. Epidemiological classification of cities according to the program of surveillance and control of visceral leishmaniasis in the State of São Paulo. Updated in December 2014. BEPA. 2015;12(143):9-22.

12. Uribe $\mathrm{S}$. The status of the Lutzomyia longipalpis species complex and possible implications for Leishmania transmission. Mem Inst Oswaldo Cruz 1999;94(6):729-34

13. Hamilton JGC, Maingon RDC, Alexander B, Ward RD, Brazil RP. Analysis of the sex pheromone extract of individual male Lutzomyia longipalpis sand flies from six regions in Brazil. Med Vet Entomol. 2005;19:480-88.

14. Warburg A, Saraiva E, Lanzaro GC, Titus RG, Neva F. Saliva of Lutzomyia longipalpis sibling species differs in its composition and capacity to enhance leishmaniasis. Philos Trans R Soc Lond B Biol Sci. 1994;345(1312):223-30.

15. Maingon RD, Ward RD, Hamilton JG, Bauzer LG, Peixoto AA. The Lutzomyia longipalpis species complex: does population sub-structure matter to Leishmania transmission. Trends Parasitol. 2008;24(1):12-7.

16. Araki AS, Ferreira GE, Mazzoni CJ, Souza NA, Machado RC, Bruno RV, Peixoto AA. Multilocus analysis of divergence and introgression in sympatric and allopatric sibling species of the Lutzomyia longipalpis complex in Brazil. PLoS Negl Trop Dis. 2013;7(10):e2495.

17. Araki AS, Vigoder FM, Bauzer LG, Ferreira GE, Souza NA, Araújo IB, et al. Molecular and behavioral differentiation among Brazilian populations of Lutzomyia longipalpis (Diptera: Psychodidae: Phlebotominae). PLoS Negl Trop Dis. 2009;3(1):e365.

18. Casanova C, Colla-Jacques FE, Hamilton JG, Brazil RP, Shaw JJ. Distribution of Lutzomyia longipalpis chemotype populations in São Paulo state, Brazil. PLoS Negl Trop Dis. 2015;9(3):e0003620

19. Casanova C, Hamilton JGC, Trigo JR, Costa Al. Identification of sex pheromones of Lutzomyia longipalpis (Lutz \& Neiva. 1912) populations from the state of São Paulo, Brazil. Mem Inst Oswaldo Cruz. 2006:101:113-15.

20. Hamilton JG, Maingon RD, Alexander B, Ward RD, Brazil RP. Analysis of the sex pheromone extract of individual male Lutzomyia longipalpis sandflies from six regions in Brazil. Med Vet Entomol. 2005;19(4):480-8.

21. Lafferty KD. The ecology of climate change and infectious diseases. Ecology. 2009;90:888-900.

22. Reisen WK. Estimation of vectorial capacity: introduction. Bull Soc Vector Ecol. 1989;14:39-40.

23. Gomes AC. Vigilância entomológica. Inf Epidemiol SUS. 2002;11(2):79-90

24. Alexander B, Carvalho RL, McCallum H, Pereira MH. Role of the domestic chicken (Gallus gallus) in the epidemiology of urban visceral leishmaniasis in Brazil. Emerg Infect Dis. 2002;8(12):1480-85.

25. Reisen WK. Landscape epidemiology of vector-borne diseases. Annu Rev Entomol. 2010;55:461-83

26. D'Andrea LAZ, Camargo-Neves VLF, Sampaio SMP, Kronka SN, Sartor IF. American visceral leishmaniasis: disease control strategies in Dracena microregion in alta paulista SP, Brazil. J Venom Anim Toxins Incl Trop Dis. 2009:15(2):305-24

27. Brasil. Ministério da Saúde. Secretaria de Vigilância em Saúde. Departamento de Vigilância Epidemiológica. Manual de vigilância e controle da leishmaniose visceral/. Ministério da Saúde, Secretaria de Vigilância em Saúde, Departamento de Vigilância Epidemiológica. Brasília: Editora do Ministério da Saúde; 2006. p. 120

28. CVE. Centro vigilância epidemiologia do estado de São Paulo. Avaliable in http:// www.saude.sp.gov.br/cve-centro-de-vigilancia-epidemiologica-prof-alexandrevranjac/areas-de-vigilancia/doencas-de-transmissao-por-vetores-e-zoonoses/ agravos/leishmaniose-visceral/dadosestatisticos. Accessed 15 Jul 2016.

29. Peel MC, Finlayson BL, McMahon TA. Updated world map of the KöppenGeiger climate classification. Hydrol Earth Syst Sci. 2007;11:1633-44.

30. IBGE. Instituto Brasileiro de Geografia e Estatística. Cidades. Avaliable in http://www.cidades.ibge.gov.br/xtras/perfil.php?lang=\&codmun=353540 Accessed 15 Jul 2016

31. Bortoletto DV, Utsunomiya YT, Perri SH, Ferreira F, Nunes CM. Age structure of owned dogs under compulsory culling in a visceral leishmaniasis endemic area. Cad Saude Publica. 2016:32(8):e00026115.

32. Galati EAB. Phlebotominae (Diptera. Psychodidae): Classificação. morfologia. terminologia e identificação de adultos. Apostila da Disciplina HEP 5752Bioecologia e Identificação de Phlebotominae. São Paulo: Faculdade de Saúde Pública. Universidade de São Paulo; 2014. p. 1-120.

33. Salomón OD, Wilson ML, Munstermann LE, Travi BL. Spatial and temporal patterns of phlebotomine sand flies (Diptera: Psychodidae) in a cutaneous leishmaniasis focus in northern Argentina. J Med Entomol. 2004;41(1):33-9. 
34. Diniz MM, Ovallos FG, de Castro Gomes CM, de Oliveira Lavitschka C, Galati EA. Host-biting rate and susceptibility of some suspected vectors to Leishmania braziliensis. Parasit Vectors. 2014;7:139.

35. Bruford MW, Hanotte O, Brookfield JFY, Burke T. Multilocus and singlelocus DNA fingerprinting. In: Hoelzel AR, editor. Molecular genetic analysis of populations: a practical approach. 2nd ed. Oxford: IRL Press; 1998. p. 287-336.

36. Noyes HA, Stevens JR, Teixeira M, Phelan J, Holz P. A nested PCR for the ssrRNA gene detects Trypanosoma binneyi in the platypus and Trypanosoma sp. in wombats and kangaroos in Australia. Int J Parasitol. 1998;29(2):331-9.

37. Altschul SF, Madden TL, Schäffer AA, Zhang J, Zhang Z, Miller W, Lipman DJ. Gapped BLAST and PSI-BLAST: a new generation of protein database search programs. Nucleic Acids Res. 1997;25:3389-402.

38. CIIAGRO. Centro integrado de informaçōes agrometeorológicas. Available in http://www.ciiagro.sp.gov.br/. Accessed Nov 2014.

39. Paiva BR, Secundino NFC, Nascimento JC, Pimenta PF, Galati EA, Junior HF, Malafronte RS. Detection and identification of Leishmania species in fieldcaptured phlebotomine sand flies based on mini-exon gene PCR. Acta Trop. 2006:99:252-9.

40. Fernández MS, Salomón OD, Cavia R, Perez AA, Acardi SA, Guccione JD. Lutzomyia longipalpis spatial distribution and association with environmental variables in an urban focus of visceral leishmaniasis, Misiones, Argentina. Acta Trop. 2010;114:81-7.

41. Oliveira EF, Silva EA, Fernandes CE, Paranhos Filho AC, Gamarra RM, Ribeiro AA, Brazil RP, Oliveira AG. Biotic factors and occurrence of Lutzomyia longipalpis in endemic area of visceral leishmaniasis. Mato Grosso do Sul. Brazil. Mem Inst Oswaldo Cruz. 2012;107(3):396-401.

42. Dye C, Davies CR, Lainson R. Communication among phlebotomine sand flies: a field study of domesticated Lutzomyia longipalpis populations in Amazonian Brazil. Anim Behav. 1991;42:183-92.

43. Soares RP, Turco SJ. Lutzomyia longipalpis (Diptera: Psychodidae: Phlebotominae): a review. An Acad Bras Cienc. 2003;75(3):301-30.

44. Rebêlo JM. Hourly frequency and seasonality of Lutzomyia longipalpis (Diptera: Psychodidae: Phlebotominae) on São Luís Island, Maranhão, Brazil. Cad Saude Publica. 2001;17(1):221-7.

45. Resende MC, Camargo MC, Vieira JR, Nobi RC, Porto MN, Oliveira CD, et al. Seasonal variation of Lutzomyia longipalpis in Belo Horizonte, State of Minas Gerais. Rev Soc Bras Med Trop. 2006;39(1):51-5.

46. Silva EA, Andreotti R, Honer MR. Comportamento de Lutzomyia longipalpis. vetor principal da leishmaniose visceral americana. em Campo Grande. Estado do Mato Grosso do Sul. Rev Soc Bras Med Trop. 2007;40:420-25.

47. Chaniotis BN, Parsons RE, Harlan HJ, Correa MA. A pilot study to control phlebotomine sand flies (Diptera: Psychodidae) in a Neotropical Rain Forest. J Med Entomol. 1982;19:1-5.

48. Barretto MP. Tese de doutorado. Contribuição para o estudo da biologia dos flebótomos em condições experimentais (Diptera: Psychodidae). São Paulo: Faculdade de Medicina da USP; 1942.

49. Meyer RP. Pathogen incubation and vector compertence. Bull Soc Vector Ecol. 1989;14:60-6.

50. Holcman MM, Sampaio SM, Rangel O, Casanova C. Spatial and seasonal distribution of Lutzomyia longipalpis in Dracena, a city in the western region of the State of São Paulo, Brazil that is endemic with visceral leishmaniasis. Rev Soc Bras Med Trop. 2013;46(6):704-12.

51. Lainson R, Shaw JJ, Ryan L, Ribeiro RSM, Silveira FT. Leishmaniasis in Brazil. Visceral leishmaniasis in the Amazon Region and further observations on the role of Lutzomyia longipalpis (Lutz \& Neiva. 1912) as the vector. Trans R Soc Trop Med Hyg. 1985;79:222-26.

52. Sherlock IA. Ecological interactions of visceral leishmaniasis in Bahia. Mem Inst Oswaldo Cruz. 1996;91:671-83.

53. Savani ES, Nunes VL, Galati EA, Castilho TM, Zampieri RA, Floeter-Winter LM. The finding of Lutzomyia almerioi and Lutzomyia longipalpis naturally infected by Leishmania spp. in a cutaneous and canine visceral leishmaniases focus in Serra da Bodoquena, Brazil. Vet Parasitol. 2009;9(1-2):18-24.

54. Soares MR, Carvalho CC, Silva LA, Lima MS, Barral AM, Rebêlo JM, Pereira SR. Molecular analysis of natural infection of Lutzomyia longipalpis in an endemic area for visceral leishmaniasis in Brazil. Cad Saude Publica. 2010;26(12):2409-13.

55. Michalsky EM, Guedes Kde S, Lara e Silva F, França-Silva JC, Dias CL, Barata RA, Dias ES. Natural infection with Leishmania infantum chagasi in Lutzomyia (Lutzomyia) longipalpis (Diptera: Psychodidae) sand flies captured in the municipality of Janaúba, State of Minas Gerais, Brazil. Rev Soc Bras Med Trop. 2010;44(1):58-62.

\section{Submit your next manuscript to BioMed Central and we will help you at every step:}

- We accept pre-submission inquiries

- Our selector tool helps you to find the most relevant journal

- We provide round the clock customer support

- Convenient online submission

- Thorough peer review

- Inclusion in PubMed and all major indexing services

- Maximum visibility for your research

Submit your manuscript at www.biomedcentral.com/submit
Biomed Central 